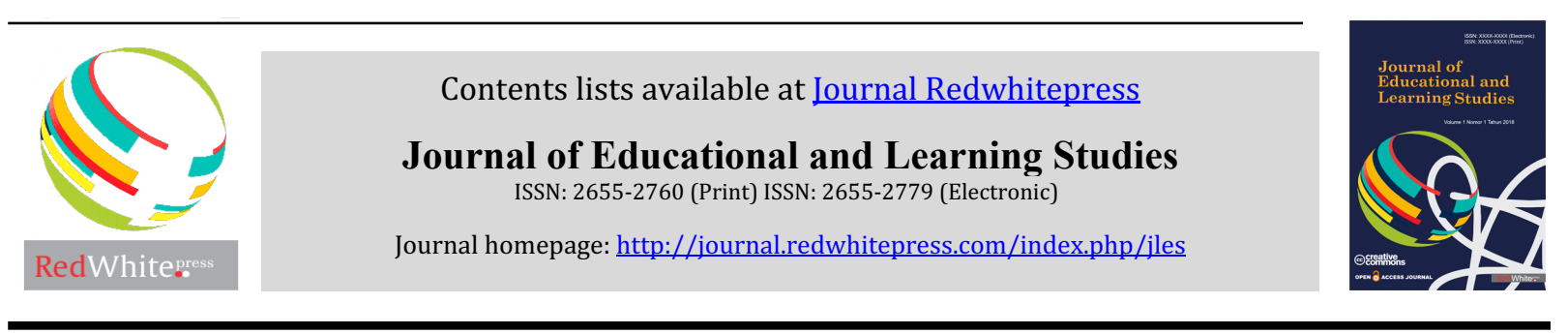

\title{
Group Guidance Effectiveness through Bibliotherapy to Reduce Academic Anxiety
}

\author{
Olivia Sriferina $^{1}$, Alizamar $^{1}$, Marjohan $^{1}$ \\ ${ }^{1}$ Universitas Negeri Padang
}

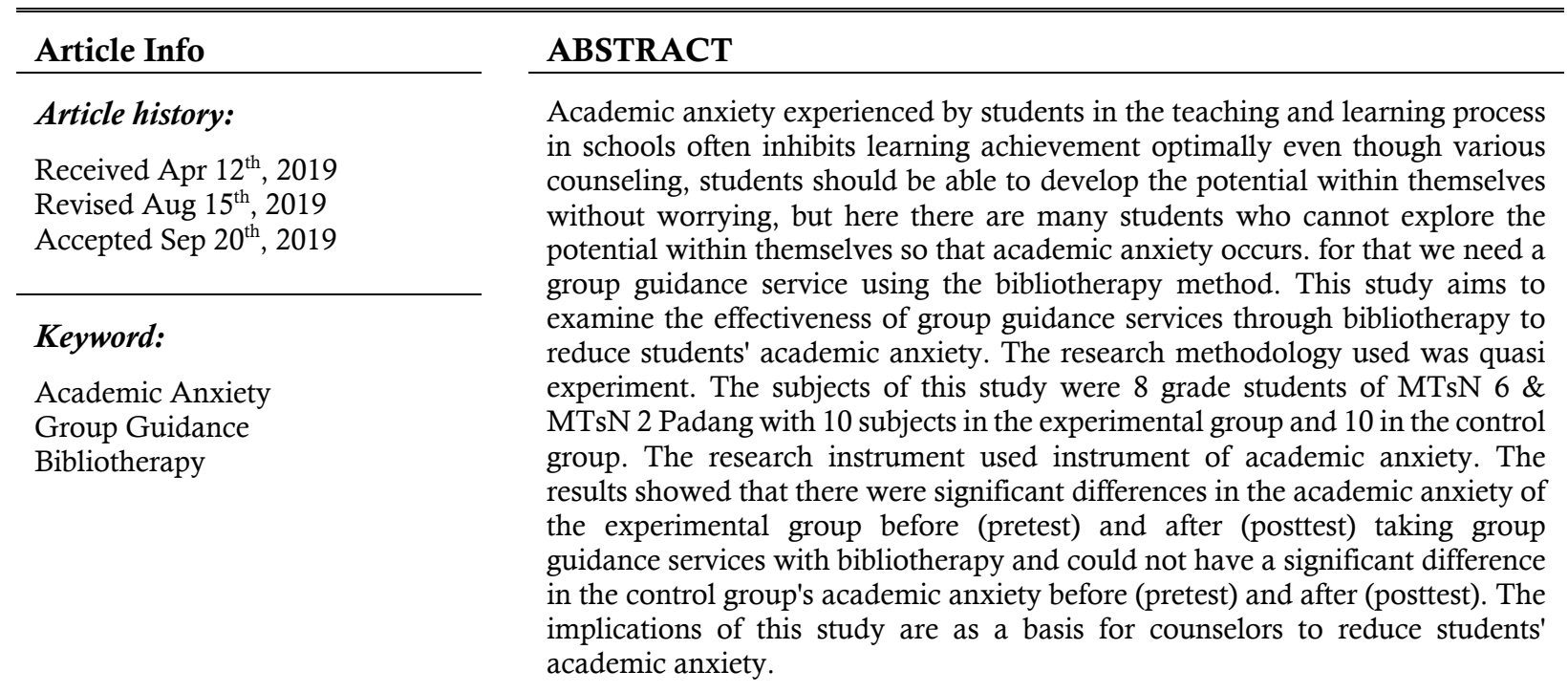

(C) 2019 The Authors. Published by Redwhitepress.

This is an open access article under the CC BY-NC-SA license

(https://creativecommons.org/licenses/by-nc-sa/4.0/

\author{
Corresponding Author: \\ Olivia Sriferina, \\ Universitas Negeri Padang \\ Email: oliviasriferina25@gmail.com
}

\section{Introduction}

The emotional increase that occurs quickly in early adolescence is known as the storm and stress. This emotional increase is the result of physical changes, especially hormones that occur in adolescence (Monks \& Knoers, 2013; Zakarsih, 2017). Middle school students (SMP/MTs) are at the stage of adolescent development. Individuals are said to enter the development stage of adolescents if they are 12-21 years old (Ali \& Asrori, 2011; Jahja, 2013). Adolescents have unstable emotions, have entered a wider social world where the influence of friends and social environment will greatly determine the level of anxiety experienced by students (Fatimah, 2006; Prayitno \& Amti, 2006; Santrock, 2014). Anxiety has a big effect on the academic performance of students, a high education system makes academic anxiety appear in students (Dorcas \& Evans, 2015). The higher academic anxiety felt by students, the lower the academic integrity of students, academic anxiety has a large influence on school performance and in adolescence has high academic anxiety levels (Firmantyo \& Alsa, 2016; Misra \& Mac Kean, 2000 ; Ottens, 1991). Academic anxiety is considered to have a negative relationship with student learning achievement (Rana \& Mahmood, 2010) Students who have high academic anxiety levels experience palpitations, sweating and panic in dealing with academic-related problems (Alizamar, 2017). In 
addition, high academic anxiety will also lead to a decrease in learning motivation possessed by students in academic activities. This situation will have a negative impact on the learning achievement achieved by students (Djumadi, 2015).

The results of the research conducted by Harlini \& Rola (2014) reveal that students who experience academic anxiety find it difficult to receive information and lose the regulatory process so that it involves shortterm memory. Academic anxiety reduces activity in rearranging information in memory. The study conducted by Etiafani (2015) as many as $52.3 \%$ of students who experienced high academic anxiety due to lack of preparation and motivation in learning was due to students lacking initiative and not serious in completing the tasks given by the teacher. Academic anxiety correlates with postponement of tasks and dysfunctional thinking which results in students giving up easily, being lazy, decreasing student performance, and decreasing learning outcomes obtained at school (Chow, 2011; Flettetal, 2012; Savithri, 2014).

Students should be able to develop the potential within themselves without worrying, but here there are many students who cannot explore the potential within themselves so that academic anxiety occurs. There are students delaying assignments, fear and worry related to academics, low learning motivation of students, tension and heart palpitations when dealing with academic problems, students are not independent and are not optimal in completing tasks, not confident, have self-talk negative, unable to concentrate and decreased thinking power.

Overcoming academic anxiety can be done by applying group guidance services through effective modeling to increase students' confidence or confidence in a better category. Students are confident about their ability to face exams, they are confident that they can defend themselves, and they are confident to regulate their ability to face situations or conditions that exist (Marjohan, 2016). Group guidance can be used by group participants to discuss problems related to personal, social, learning and career fields (Queener \& Kenyon, 2011). The knowledge of group leaders and skills in facilitating group members can help group members discuss topics discussed (Paisley \& Milsom, 2006). The group guidance in this study used the bibliotherapy method as an additional method to overcome students' academic anxiety.

Bibliotherapy is one of the most effective things in increasing the creativity of students. Bibliotherapy helps and motivates participants to provide awareness and understanding of the problems faced by students by reading books (Endang, 2017). Research conducted by Yoanda (2015) that bibliotherapy can provide a sense of calm, comfort, security to students who experience academic anxiety. Bibliotherapy is light reading material that provides information to students so that they can reduce anxiety about the problems they experience. Trihantoro (2016) says that bibliotherapy helps them develop positive thinking about themselves. Information obtained from books becomes input to overcome the problems faced. Through reading students can interpret the meanings of reading, such as feelings of emotion, sympathy, and others. These feelings can improve students to behave adaptively. Many studies on bibliotherapy that show its effectiveness in overcoming psychological problems both children and adults (Fitria, 2016).

The results of research conducted by Rahmat \& Chanum (2016) revealed that $72 \%$ of bibliotherapy techniques had a positive effect on students' self-concept. Bibliotherapy can be done by counseling teacher as an alternative treatment for students who have negative self-concept in terms of academic anxiety. the results of the study, there were 267 children ranging in age from 6 to 12 years experiencing clinical anxiety, one method used to reduce anxiety was a bibliotherapy method with a period of $12-24$ weeks with a percentage of $15 \%$ of children free from anxiety levels (Gregory, 2004). These conditions need attention from the school including counselors so that these problems can be alleviated. Therefore, research needs to be done to obtain accurate data on the description of students' academic anxiety at school. The results of this study can be a reference and input for Counselors to provide appropriate guidance and counseling services to students to reduce academic anxiety.

\section{Method}

This study is quasi-experimental to see the level of academic anxiety of students before and after being given treatment by group guidance services using the bibliotherapy method. Subjects in this study were eighth grade students of MTsN 6 \& MTsN 2 Padang, totaling 10 people (experimental group) and 10 people (control group). Subject taking begins with identifying the level of academic anxiety experienced by students using the instrument. The instrument used was an academic anxiety level questionnaire developed by researchers with a instrument academic anxiety. The data obtained were analyzed using percentage techniques. The results of the analysis of the data obtained then this study took the subject of 10 students with different levels of academic anxiety (heterogeneous) to become the dynamics in group guidance later.

\section{Results}


The results of the study on the level of academic anxiety significantly through the application of group guidance with the bibliotherapy method were analyzed descriptively. The tables and images below show the percentage as follows.

Table 1. Comparison of the Pretest Academic Anxiety and Posttest Experimental Group Scores

\begin{tabular}{ccccc}
\hline & \multicolumn{3}{c}{ Pretest } & \multicolumn{2}{c}{ Posttest } \\
\cline { 2 - 5 } Eode & Skore & Category & Skore & Category \\
\hline E2 & 141 & Moderate & 99 & Low \\
\hline E3 & 144 & High & 113 & Moderate \\
\hline E4 & 108 & Low & 102 & Low \\
\hline E5 & 140 & Moderate & 107 & Low \\
\hline E6 & 141 & Moderate & 100 & Low \\
\hline E7 & 134 & Moderate & 103 & Low \\
\hline E8 & 137 & Moderate & 104 & Low \\
\hline E9 & 150 & High & 109 & Moderate \\
\hline E10 & 155 & High & 112 & Moderate \\
\hline Rata-rata & 141,5 & High & 110 & Low \\
\hline
\end{tabular}

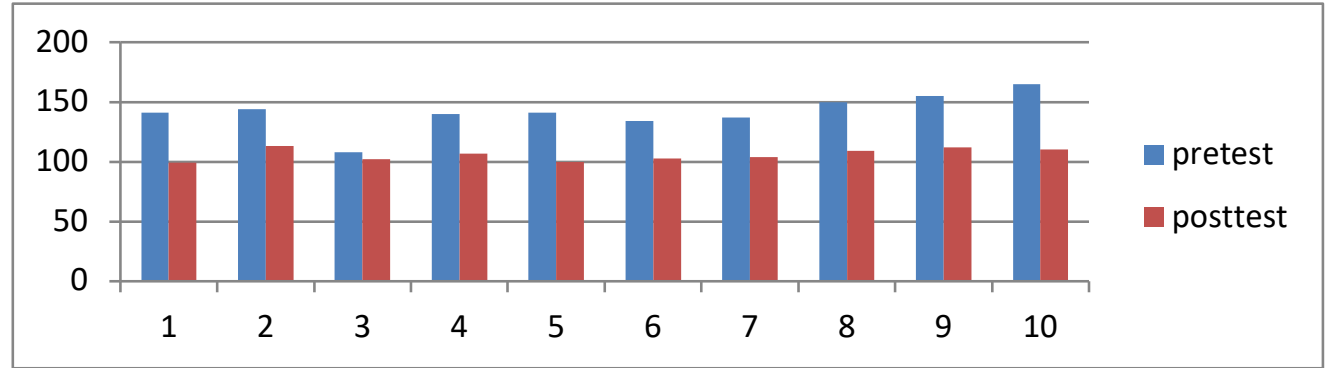

Figure 1. Experimental and Posttest Histogram of Experimental Academic Anxiety Group

Based on the above graph in general, all members of the experimental group who had carried out group guidance with bibliotherapy had decreased levels of academic anxiety. The findings of the study showed that students' academic anxiety decreased significantly through the application of group guidance services with bibliotherapy. Bibliotherapy is the use of literature in treatment for people who experience emotional problems or academic anxiety. Bibliotherapy is often used in group work and group therapy and is reported to be effective for all people of various age groups, also effective for healthy people who want to share literature that is useful for personal growth and development (Herlina, 2013).

Table 2. Comparison of pretest academic anxiety scores and control group posttest 


\begin{tabular}{ccccc}
\hline \multirow{2}{*}{ Code } & \multicolumn{2}{c}{ Pretest } & \multicolumn{2}{c}{ Posttest } \\
\cline { 2 - 5 } & Skore & Category & Skore & Category \\
\hline K1 & 108 & Low & 106 & Low \\
\hline K2 & 139 & Moderate & 133 & Moderate \\
\hline K3 & 127 & Moderate & 132 & Moderate \\
\hline K4 & 129 & Moderate & 126 & Moderate \\
\hline K5 & 154 & High & 145 & High \\
\hline K6 & 152 & High & 144 & High \\
\hline K7 & 141 & Moderate & 145 & High \\
\hline K8 & 121 & Moderate & 120 & Moderate \\
\hline K9 & 148 & High & 129 & Moderate \\
\hline K10 & 129 & Moderate & 127 & Moderate \\
\hline Rata-rata & 134,8 & Moderate & 131,5 & Moderate
\end{tabular}

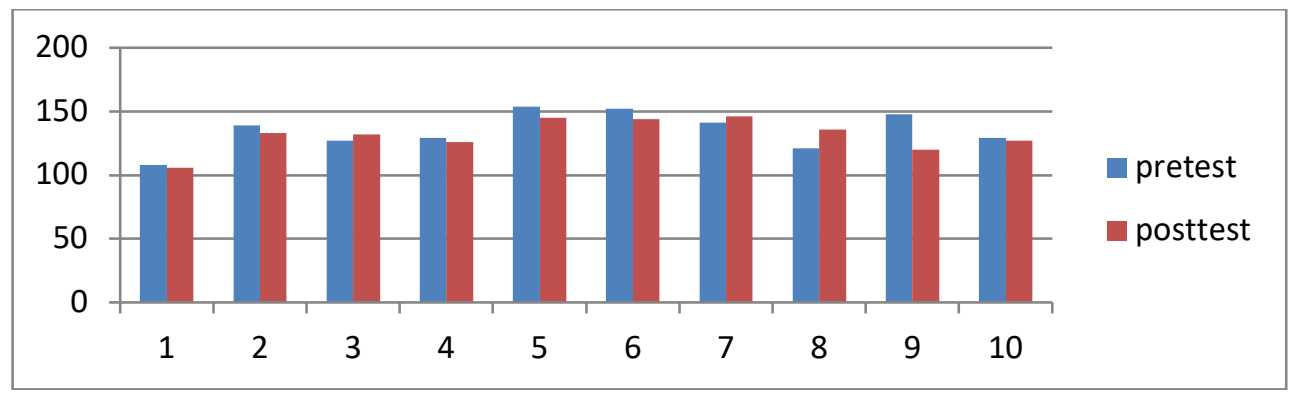

Figure 2. Pretest and Posttest Histogram of Control Group Academic Anxiety

Based on the above graph in general the control group members who were not given treatment in the form of group guidance services with bibliotherapy did not experience a decrease in the level of academic anxiety. Judging from the comparison of the results of the pretest and posttest control group did not experience a decrease in academic anxiety. This finding proves that group guidance services with bibliotherapy can reduce students' academic anxiety at school. This means that the implementation of group guidance services with bibliotherapy can reduce academic anxiety.

\section{Discussion}

The results showed that the students' academic anxiety levels in the experimental group and the control group before being given group guidance treatment with bibliotherapy were in the high category. The high level of academic anxiety is influenced by environmental factors and unpreparedness in receiving lessons in school (Mulyani, 2013). High academic anxiety can result in low achievement and learning outcomes (Popoola, 2015). In reducing academic anxiety in the school group guidance is carried out with a bibliotherapy where bibliotherapy is chosen because it can bring individuals closer to the book and make individuals accustomed to reading. Bibliotherapy experts identify the function of bibliotherapy as a formation of individual life through growth awareness (Trihantoro, 2016). Therefore bibliotherapy can be applied as one of the guidance techniques 
for the development of moral behavior, bibliotherapy has benefits as a nurturent effect, namely the acquisition of knowledge about reading material (Dewi \& Prihartanti, 2014).

Groups that are widely used, small groups, or strategies of individual students where the stories in the book are used to make connections between students and characters who have similar emotional experiences. This connection helps students find solutions and insights into their own feelings. After the book has been read, the teacher involves students in discussions about stories related to perfectionism, incorporating the instructions and questions needed (Audrey, 2013). Using books for healing psychological health including academic anxiety is becoming popular day by day. In this process bibliotherapy puts forward suggestions for psychological insights, eliminates by identification, freeing from feeling depressed with use and reflecting emotions (Bayram, 2016).

The results of the study in the experimental group after being given treatment in the form of group guidance with bibliotherapy were in the medium category. This shows that group guidance services with bibliotherapy are effective in reducing students' academic anxiety. Unlike the control group that was not given treatment, there was no significant decrease in the level of academic anxiety. Reading books is recognized as a means to help individuals face deep concerns and can offer specific strategies for developmental problems (Pehrshon, 2007).

The limitations of this study in the reading books that are used in one book for one meeting are expected to be more effective and increase the insight of students given the choice of reading books with at least 6 books that students can choose to alleviate the problems related to academic anxiety in school.

\section{Conclusion}

Through this study, it was concluded that students had experienced a decrease in the level of academic anxiety in school. This needs to be maintained and the attention of BK / Counselor teachers in schools as professionals through guidance and counseling services in schools to help students reduce academic anxiety in schools so that students can actualize themselves in schools to support the learning process and their learning and achievements in school.

\section{References}

Ali, M., \& Asrori, M. (2011). Psikologi Remaja: Perkembangan peserta didik. Jakarta: Bumi Aksara.

Alizamar\& Asri (2017).Tingkat Kecemasan Siswa dalam Menghadapi Ujian Sekolah Ditinjau dari Jenis Kelamin, Jurusan dan Daerah Asal Serta Implikasinya. Jurnal Bikotetik. Vol 1 (2): 37-72

Audrey, C. Rule. (2013). Teaching Primary Grade Students Perfectionism Through Cartoons Compared to Bibliotherapy. Journal of Elementary Education. Vol 5 (2): 199-128.

Bayram, A. (2016). The Impact of Biblio Group Counseling Supported With The Story of The Little Prince Upon Mindfullness. Journal Education. Vol 4 (6): 1-11.

Dewi, N \& Prihartanti, N. (2014). Metode Bibliotherapy dan Diskusi Dilema Moral untuk Pengembangan Karakter Tanggung Jawab. Jurnal Psikologi. Vol 4 (1): 47-59.

Djumadi, A. (2015). Hubungan Antara Tingkat Kecemasan dengan Prestasi Akademik Mahasiswa di Fakultas Psikologi Muhammadiyah Surakarta. Jurnal Psikologi. Vol 1(2): 17-20.

Dorcas \& Evans. (2015). The Relationship Between Anxiety and Academic Performance of Postgraduate International Students in a British University: A Cross-Sectional Quantitative Design. Science Journal of Public Health. Vol 3(3): 331-338.

Endang, Y. (2017). Pengaruh Biblioterapi Terhadap Peningkatan Kreatifitas Verbal pada Anak Usia Sekolah. Jurnal Ners. Vol 9 (2) : 13-20.

Etiafani \& Listiara, A. (2015). Self Regulated Learning dan Kecemasan Akademik pada Siswa SMK. Jurnal Empati. Vol 4 (4) : 144-149.

Fatimah, E. 2006. Psikologi Perkembangan (Perkembangan Peserta Didik). Bandung: Pustaka Setia.

Firmantyo, F \& Alsa. (2016). Integritas Akademik dan Kecemasan Akademik dalam Menghadapi UN Pada Siswa. Jurnal Psikologi. Vol 1 (1): 1-11. 
Fitria, Yeni. (2016). Bibliotherapy : A Cognitive Behaviour Therapy Approach to Promote Psychologycal Well Being. Jurnal of Nursing Care. Vol 1(1) : 34 .

Gregory, Vessey. (2004). Bibliotheraphy A Strategy To Help Students With Bullying. Jurnal. School Nursing. Vol. 20. 127.

Harlini, NL \& Rola, F. (2014). Hubungan Antara Kecemasan Akademik dengan Academic Self Management pada Siswa SMA Kelas X Unggulan. Jurnal Psikologi. Vol 1 (1). 15-23.

Herlina. (2013). Bibliotherapy Mengatasi Masalah Anak dan Remaja Melalui Buku. Bandung: Pustaka Cendikia Utama.

Jahja, Y. (2013). Psikologi Perkembangan. Jakarta: Kencana.

Marjohan, \& Anggara F. (2016). Efektifitas Layanan Bimbingan Kelompok dengan Modeling dalam meningkatkan Efikasi Diri Siswa dalam Menghadapi Ujian. Jurnal Konselor. Vol 5 (1). 42-49.

Monks, F. J., \& Knoers, A. M. P. (2013). Psikologi Perkembangan: Pengantar dalam berbagai bagiannya. Yogyakarta: Gajah Mada University Press.

Mulyani, D. (2013). Hubungan Kesiapan Belajar Siswa dengan Prestasi Belajar. Jurnal Konselor. Vol 2(1).

Misra, R. \& McKean, M. (2000). College Students' academic stress and its relation to their anxiety, time management, and leisure satisfaction. American Journal of Health Studies.

Ottents, A. J. (1991). Coping with Academy Anxiety. New York: The Rosen Publishing Group.

Paisley, P.O., dan Milsom, A. 2006. "Group Work as an Essential Contribution to Transforming School Counseling". The Journal for Specialists in Group Work, 32 (1): 9-17.

Pehrsson, D.E. (2007). Bibliotherapy : Overview and Implications for Counselors. (ACAPCD-02). Alexandria. VA:ACA.

Popooala, B. I. 2005. A Study of Procrastinatory Behavior and Academic Performance of Undergraduate Students in South Western Nigeria. Journal od Social Science, 11 (3): 215-218.

Prayitno \& Amti, E. (2006). Psikologi Perkembangan Remaja. Padang: Angkasa Raya.

Queener, J.E., dan Kenyon, C.B. 2001. "Providing Mental Health Services to Southeast Asian Adolescent Girls: Integration of a primary prevention paradigm and group counseling". The Journal for Specialists in Group Work. 26 (4): 350-367.

Rahmat, H.D \& Chanum, I. (2016). Pengaruh Teknik Bibliotherapy untuk Mengubah Konsep Diri Siswa. Jurnal Bimbingan Konseling. Vol 5 (1) : 8-13.

Rana, R.A and Mahmood, N. (2010). The Relationship Between Test Anxiety and Academik Achievement. Jurnal. Vol 2(2): 182-196.

Santrock, J. W. (2014). Adolescence-Fifteenth edition. New York: McGraw-Hill Education.

Trihantoro, A. (2016). Pengaruh Teknik Biblioterapi untuk Mengubah Konsep Diri Siswa. Jurnal Bimbingan Konseling. Vol 5 (1).

Yoanda, S. (2015). Layanan Biblioterapi untuk Pasien Kanker Anak di RSUP Fatmawati Jakarta. Jurnal Yasri. Vol 2 : 125-131.

Zarkasih, P.K. (2017). Memahami Ciri dan Tugas Perkembangan Remaja. Jurnal Aplikasi Ilmu Agama. Vol 17 (1): 25-32. 